\title{
UPAYA MENINGKATKAN BUDAYA MENULIS SISWA TUNAGRAHITA PADA MATA PELAJARAN BAHASA INDONESIA DENGAN MENGGUNAKAN MUSBAR DI KELAS VII-VIII. C SLB AL-AZHAR BUKITTINGGI
}

\begin{abstract}
Yunilda
SLB Al-Azhar Bukittinggi, Indonesia

Email: yunildawaung@gmail.com

\section{INFORMASI ARTIKEL}

\section{Terkirim 10 Juni 2019}

Revisi 20 Juni 2019

Diterima 20 September 2019

\section{Kata kunci:}

Kamus Bergambar, Menulis, Siswa

Tunagrahita

ABSTRAK

Penelitian ini dilatarbelakangi oleh adanya permasalahan Proses pembelajaran menulis pada mata pelajaran bahasa Indonesia yang dilaksanakan selama ini untuk siswa Berkebutuhan Khusus kategori tunagrahita ringan masih dalam taraf menulis nama benda atau kalimat yang sangat sederhana sehingga siswa tidak mempunyai kesempatan untuk membangun sendiri ide-idenya dan mengaitkan materi dengan kehidupan siswa, terlihat bahwa pada umumnya siswa tunagrahita dikelas tersebut mampu membaca dan menulis tetapi masih sulit dalam menulis sesuatu yang ia lihat atau rasakan.

Metode yang digunakan dalam penelitian ini adalah Penelitian Tindakan Kelas (PTK) diawali dengan perencanaan tindakan, penerapan tindakan, mengobservasi dan mengevaluasi proses dan hasil tindakan, dan melakukan refleksi, dan seterusnya sampai perbaikan atau peningkatan yang diharapkan.

Keempat tahap tersebut dilaksanakan dalam 2 siklus penelitian, dimana setiap siklus difokuskan tentang menulis pengalaman/karangan sederhana dan menulis puisi yang berkaitan dengan gambar. Penelitian ini dilaksanakan di SLB Al-Azhar Bukittinggi dengan subjek penelitian kelas VII-VIII.C yang terdiri dari siswa tunagrahita ringan. Tujuan penelitian ini adalah untuk meningkatkan budaya menulis pada mata pelajaran bahasa Indonesia dan upaya peningkatkan budaya menulis ini dengan melaksanakan 2 program yaitu : 1). To week's story, (Kegiatan ini merupakan pembiasaan siswa tunagrahita untuk menulis menulis pengalamannya dalam bentuk karangan singkat satu minggu satu karangan, 2). One week one poety, (satu minggu satu puisi) dan hasil terbukti dari hasil ditunjukkannya peningkatan hasil dari observasi awal tidak ada yang mampu dan hanya 1 orang siswa (25\%) yang kurang mampu pada siklus I 1 Orang siswa (25\%) yang mampu dan pada siklus II meningkat menjadi 3 orang (75\%) yang mampu dan 1 orang $(25 \%)$ yang kurang mampu. dari jumlah keseluruhan 4 orang siswa. Berdasarkan standar tersebut, penelitian tindakan kelas ini menunjukkan hasil.
\end{abstract}

\section{Pendahuluan}

Menulis merupakan salah satu dari empat keterampilan berbahasa. Menulis bukan hanya menyalin tetapi juga mengekspresikan pikiran dan perasaan kedalam lambang-lambang tulisan. Menurut Mc. Crimmon dalam St.Y. Slamet (2008: 141), bahwa menulis merupakan kegiatan menggali pikiran dan perasaan mengenai suatu subjek, memilih hal-hal yang akan ditulis, menentukan cara menuliskannya sehingga pembaca dapat memahaminya dengan mudah dan jelas. terhadap simbol-simbol bahasa tersebut.

Sesuai dengan isi Peraturan Direktur Jenderal Pendidikan Dasar dan Menengah Nomor: 10/D/KR/2017 tentang Struktur Kurikulum, Kompetensi Inti-Kompetensi Dasar, dan Pedoman Implementasi Kurikulum 2013 Pendidikan Khusus. Untuk mata pelajaran Bahasa Indonesia bagi anak tunagrahita tingkat SMPLB diharapkan memahami pengetahuan faktual dengan cara mengamati [mendengar, melihat, membaca] dan menanya berdasarkan rasa ingin tahu tentang dirinya, makhluk ciptaan Tuhan dan kegiatannya, dan benda-benda yang dijumpainya di rumah di sekolah, dan tempat bermain, sehingga dapat dijadikan acuan bagi guru kelas dalam mengembangkan 4 kemampuan berbahasanya salah satunya menulis.

Anak tunagrahita ringan memiliki visual processing skills lebih baik sehingga dapat diberikan pembelajaran menulis yang menggunakan media yang kongret dan semi kongret, sebab anak tunagrahita dengan katagori ringan banyak yang lancar berbicara, mengalami kesukaran berfikir abstrak tetapi masih mampu mengikuti kegiatan akademik dalam batas- batas tertentu.

Proses pembelajaran menulis yang dilaksanakan selama ini oleh guru kelas masih dalam taraf menulis nama benda atau kalimat yang sangat sederhana yang mengandung SPO, dan siswa tidak mempunyai kesempatan untuk membangun sendiri ide-idenya dan mengaitkan materi dengan kehidupan siswa, disebabkan media untuk membelajaran menulis untuk anak tunagrahita di kelas VII-VIII.C masih sangat sederhana dan tidak menarik, sehingga tidak dapat menginspirasi siswa dalam merangkai sebuah kalimat menjadi sebuah paragraf berupa cerita pendek atau puisi sederhana, sehingga hasil yang ingin dicapai pada kompetensi dasar untuk dapat menceritakan teks cerita sehari-hari secara sederhana dalam bahasa Indonesia secara tulisan masih belum terpenuhi sesuai dengan KKM yang ada, ini berdasarkan data yang diperoleh dari hasil observasi selama melaksanakan proses kegiatan belajar mengajar mata pelajaran bahasa Indonesia, terlihat bahwa pada umumnya siswa tunagrahita di kelas tersebut mampu membaca dan serta luwes berkomunikasi secara lisan, tetapi masih sulit dalam menulis sesuatu yang ia lihat atau rasakan dan hasil belajar menulis siswa kelas VII-VIII.C SLB Alazhar Bukittinggi untuk mata pelajaran bahasa Indonesia dalam menulis pengalaman/mengarang dan puisi belum memenuhi kriteria ketuntasan minimal $(\mathrm{KKM})$. Hanya 1 orang siswa dari orang siswa (25\%) yang dapat memenuhi kemampuan mampu sesuai dengan kriteria yang ditetapkan, 
Untuk memecahkan masalah tersebut di atas salah satu upaya pendekatan pembelajaran yang peneliti anggap tepat dapat meningkatkan hasil menulis siswa tunagrahita adalah penerapan media Kamus Bergambar (Musbar) yang berisi nama gambar-gambar yang dijumpai siswa dalam kehidupan sehari-hari

Dari uraian diatas maka penulis perlu melakukan penelitian tindakan kelas dengan judul "Upaya meningkatkan budaya menulis siswa tunagrahita pada mata pelajaran bahasa Indonesia dengan menggunakan Musbar (Kamus bergambar) di kelas VII-VIII.C SLB Al-Azhar Bukittinggi". Rumusan masalah dalam penelitian ini adalah :" Apakah budaya menulis siswa tunagrahita pada mata pelajaran bahasa Indonesia melalui media musbar (Kamus Bergambar) di kelas VII-VIII.C SLB Al-Azhar Bukittinggi dapat ditingkatkan?" Tujuan Penelitian adalah untuk meningkatkan budaya menulis siswa tunagrahita pada mata pelajaran bahasa Indonesia melalui media Musbar (Kamus Bergambar) di kelas VII-VIII.C SLB Al-Azhar Bukittinggi .

\section{Metode}

\section{A. Jenis Penelitian}

Jenis penelitian yang dilaksanakan adalah Penelitian Tindakan Kelas yang terfokus pada upaya untuk meningkatkan budaya menulis kearah yang diharapkan.

\section{B. Waktu dan tempat penelitian}

Waktu penelitian ini dilaksanakan pada semester 2 tahun ajaran 2018/2019 selama dua bulan yaitu bulan Januari sampai Februari 2019 dengan dua siklus, setiap siklus terdiri dari dua kali pertemuan.

\section{Prosedur Siklus Tindakan dan Subjek penelitian}

1. Tahap Studi Pendahuluan dan Refleksi Awal

Studi pendahuluan berupa observasi awal terhadap kemampuan menulis siswa tunagrahita pada mata pelajaran bahasa Indonesia di kelas VIIVIII.C SLB Al-Azhar Bukittinggi sebagai subjek penelitian. Hal ini dilakukan untuk mengetahui permasalahan yang dihadapi guru dan peserta didik yang berkaitan dengan kemampuan menulis di kelas tersebut.

2. Tahap Perencanaan

Kegiatan ini dimulai dengan merumuskan rancangan tindakan pembelajaran dengan kegiatan sebagai berikut :

a. Menyusun rancangan tindakan meliputi tujuan pembudayaan literasi di kelas, memilih dan menetapkan media/sumber belajar serta evaluasi.

b. Menyusun indikator dan kriteria pembudayaan literasi menulis dengan menggunakan Musbar (kamus bergambar)

c. Menyusun instrumen pengumpulan data penelitian berupa: observasi dan catatan lapangan untuk mengumpulkan data yang ada selama pelaksanaan penelitian.

d. Membuat program pembudayaan literasi menulis

3. Tahap Pelaksanaan dan Pengamatan Tindakan

a. Tahap Pelaksanaan Tindakan

Tahap ini dimulai dari pelaksanaan program membudayakan menulis dengan kegiatan : (1) to week's story, (2) one week one poety,

b. Tahap Pengamatan

Pengamatan dilakukan oleh peneliti secara terus menerus dari siklus I sampai siklus II. Pengamatan yang dilakukan pada satu siklus dapat mempengaruhi penyusunan tindakan pada siklus selanjutnya

4. Tahap Refleksi

Refleksi dilakukan disetiap satuan tindakan berakhir. Dalam hal peneliti selaku guru kelas mengadakan diskusi dengan teman sejawat terhadap tindakan yang baru dilakukan..

\section{Teknik dan Analisis Data}

1. Teknik Pengumpulan Data

Data penelitian ini dikumpulkan dengan menggunakan teknik observasi, catatan lapangan, lembar kerja dan hasil publikasi (1) to week's story, (2) one week one poety.

2. Analisis Data

Data yang diperoleh dalam penelitian ini dianalisis dengan menggunakan analisis kualitatif dan kuantitatif. Analisis data kualitatif yaitu pengamatan dan pencatatan di lapangan, Sedangkan hasil analisis kuantitatif yaitu berkaitan dengan hasil menulis peserta didik.

3. Indikator kinerja

\section{Hasil Penelitian dan Pembahasan}

\section{A. Hasil Penelitian}

1. Siklus I

a. Perencanaan Pelaksanaan Budaya Literasi menulis di kelas Pelaksanaan pembelajaran ini dilaksanakan dalam dua siklus, dan setiap siklus dua Kali pertemuan. Pelaksanaan tindakan kelas siklus I pertemuan I dilaksanakan pada hari Rabu tanggal 16 Januari 2019 sedangkan pertemuan II dilakukan pada hari Rabu tanggal 23 Januari 2019. Untuk pelaksanaan tindakan kelas siklus II pertemuan I dilaksanakan pada hari Rabu 30 Januari 2019 dan pertemuan II terlaksana pada hari Rabu tanggal 6 Februari 2019.

b. Pelaksanaan Observasi Awal

Observasi awal terhadap kegiatan siswa selama pembelajaran dilakukan secara individual selama pembelajaran berlangsung oleh peneliti. Aspek-aspek kegiatan siswa yang diamati dan dinilai terdiri dari 2 program menulis yakni (1) to week's story, (2) one week one poety.

Berdasarkan hasil observasi awal diperoleh data melalui kegiatan guru mitra diperoleh bahwa dari 4 siswa hanya 1 atau $25 \%$ siswa yang mampu kurang mampu menulis pengalamannya, serta menulis puisi dan 3 orang siswa masih tidak mampu menulis pengalamannya dan puisi berdasarkan gambar atau $75 \%$ siswa.

c. Pelaksanaan Siklus I

Pada siklus pertemuan pertama dapat digambarkan bahwa pada siklus I kemampuan siswa menulis dari 4 orang siswa pada aspek kemampuan menghasilkan sebuah karangan / menulis pengalamannya dan menulis puisi hanya terdapat 2 orang siswa atau $50 \%$ yang kurang mampu, dan 2 orang siswa atau $50 \%$ yang tidak mampu serta yang tidak mampu.

Untuk siklus I pertemuan 2 dilaksanakan pada hari Rabu tanggal 23 Februari 2019, dapat digambarkan bahwa pada siklus I pertemuan ke dua yang ditemui dikelas VII-VIII.C SLB Al-Azhar Bukittinggi pada kemampuan siswa menulis pengalaman / mengarang,puisi melalui kamus bergambar mengalami peningkatan. Dari 4 orang siswa pada aspek kemampuan menulis pengalaman pada gambar terdapat 1 orang siswa atau $25 \%$ yang mampu, dan 2 orang siswa atau 50\% yang kurang mampu serta yang tidak mampu 1 orang siswa atau $25 \%$ 
d. Kegiatan Guru dalam Proses Pembelajaran Siklus I

Kegiatan guru dalam proses pembelajaran siklus I dapat diamati dan dinilai dengan menggunakan lembar observasi yang telah disiapkan. Berikut ini diuraikan digambarkan data hasil pengamatan kegiatan guru dalam proses pembelajaran siklus kegiatan guru dalam meningkatan budaya menulis siswa tunagrahita melalui Media Kamus Bergambar (Musbar) Di Kelas VII-VIII. C SLB Al-Azhar Bukittinggi bahwa kualifikasi pembelajarannya yaitu teridentifikasi sebagai berikut: a) dari 24 aspek yang dinilai oleh pengamat 1 (P1), dimana selaku pengamat 1 adalah guru kelas aspek yang dinilai pada peneliti dalam proses pembelajaran, terdapat 17 atau $70,8 \%$ indikator atau aspek yang telah dikuasai oleh peneliti. b) dari 18 aspek yang dinilai oleh pengamat 2 (P2), dimana selaku pengamat 2 adalah peneliti aspek yang dinilai pada guru mitra dalam proses pembelajaran, terdapat 18 atau $75 \%$ indikator atau aspek yang telah dikuasai oleh guru kelas. 70,8\%

e. Refleksi Pembelajaran Siklus I

Refleksi dilakukan melalui diskusi peneliti dengan guru mitra yang menjadi observer dalam proses pembelajaran. Refleksi dilakukan untuk memperoleh kesimpulan dari kegiatan tindakan kelas yang dilakukan pada siklus I. Dari hasil refleksi dapat disimpulkan bahwa tindakan kelas siklus I belum dapat mencapai indikator kinerja yang telah ditetapkan sebelumnya. Hal ini berarti bahwa tindakan kelas siklus I belum mencapai indikator kinerja sehingga harus dilanjutkan ke tindakan kelas siklus II.

\section{Siklus II}

\section{a. Perencanaan}

Memperhatikan catatan dan hasil yang diperoleh selama siklus I. Untuk meningkatkan budaya menulis siswa tunagrahita ringan melalu media Musbar pada siklus I pelaksanaan tindakan siklus II lebih diarahkan untuk memperbaiki dan menyempurnakan tindakan kelas yang belum terlaksana dengan baik pada siklus I serta memperbaiki bagian-bagian materi yang belum tuntas pada siklus I. Pada siklus II ini proses pembelajaran dilaksanakan dengan mengacu pada Rencana Pelaksanaan Pembelajaran (RPP).

b. Pelaksanaan

Pelaksanaan tindakan kelas siklus II pertemuan I dilaksanakan pada hari Rabu 30 Januari 2019 dan pertemuan II terlaksana pada hari Rabu tanggal 6 Februari 2019 .Dari hasil pengamatan yang dilakukan diketahui bahwa perkembangan budaya menulis melalui media Kamus Bergambar (Musbar) pada siswa tunagrahita dikelas VII-VIII.C SLB Al-Azhar Bukittinggi meningkat dibandingkan dari siklus I.

c. Kegiatan guru dan Siswa dalam Proses Pembelajaran Siklus II

Observasi terhadap kegiatan siswa selama pembelajaran siklus II dilakukan secara individual selama pembelajaran berlangsung oleh seorang guru observer, menggunakan lembaran observasi yang telah disiapkan. Berdasarkan hasil analisis observasi siklus I, maka pada tindakan siklus II guru membuat perencanaan penyempurnaan aspek-aspek kegiatan pembelajaran, baik kegiatan guru dan kegiatan siswa yang belum terlaksana dengan baik pada siklus I. pada siklus II pertemuan pertama dapat digambarkan bahwa pada siklus II yang ditemui dikelas VIIVIII.C SLB Al-Azhar Bukittinggi pada kemampuan budaya menulis pada mata pelajaran bahasa Indonesia melalui media Kamus Bergambar sudah mengalami peningkatan. Dari 4 orang siswa pada aspek kemampuan menulis pengalaman/mengarang dan menulis puisi berdasarkan gambar terdapat 2 orang siswa atau 50\% yang mampu, dan 2 orang siswa atau 50\% yang kurang mampu serta yang tidak mampu tidak ada atau $0 \%$

Pada siklus II pertemuan pertama budaya menulis siswa tunagrahita sudah mengalami peningkatan, akan tetapi belum mencapai target sesuai dengan indikator kinerja sehingga pelaksanaan tindakan masih perlu dilanjutkan lagi ke pertemuan berikutnya yakni pelaksanaa siklus II pertemuan kedua, dapat dilihat pada uraian data pada tabel di atas dari 4 orang siswa pada aspek kemampuan menulis pengalaman/memgarang terdapat 3 orang siswa atau $75 \%$ yang mampu, dan 1 orang siswa atau $25 \%$ yang kurang mampu serta yang tidak mampu tidak ada atau $0 \%$.

d. Kegiatan Guru dalam Proses Pembelajaran Siklus II

Kegiatan guru dalam proses pembelajaran siklus II dapat diamati dan dinilai dengan menggunakan lembar observasi yang telah disiapkan. Berikut ini diuraikan dan digambarkan data hasil pengamatan kegiatan guru dalam proses pembelajaran siklus II.

Kegiatan guru teridentifikasi sebagai berikut: a) Dari 24 aspek yang dinilai oleh pengamat 1 (P1), dimana selaku pengamat 1 adalah peneliti sendiri aspek yang dinilai pada peneliti dalam proses pembelajaran, terdapat 22 atau $91,6 \%$ indikator atau aspek yang telah dikuasai oleh peneliti. (b) Dari 24 aspek yang dinilai oleh pengamat 2 (P2), dimana selaku pengamat 2 adalah guru mitra aspek yang dinilai pada guru kelas dalam proses pembelajaran, terdapat juga 22 atau 91,6\% indikator atau aspek yang telah dikuasai oleh guru kelas.

e. Refleksi Pembelajaran Siklus II

Pelaksanaan tindakan siklus II dengan tujuan agar budaya menulis siswa tunagrahita pada mata pelajaran bahasa Indonsia melalui media Musbar di kelas VII-VIII.C SLB Al-Azhar Bukittinggi bisa meningkat, sudah memenuhi harapan. Dari 4 orang siswa pada aspek kemampuan menulis pengalaman/mengarang dan puisi terdapat 3 orang siswa atau $75 \%$ yang mampu/, dan 1 orang siswa (25\%) yang kurang mampu,

\section{B. Pembahasan}

Peningkatan hasil menulis siswa tunagrahita dari observasi awal tidak ada yang mampu dan hanya 1 orang siswa (25\%) yang kurang mampu dan pada siklus II meningkat menjadi 3 orang (75\%) yang mampu dan 1 orang (25\%) yang kurang mampu. dari jumlah keseluruhan 4 orang siswa. Berdasarkan standar tersebut, penelitian tindakan kelas ini menunjukkan hasil garfik berikut :

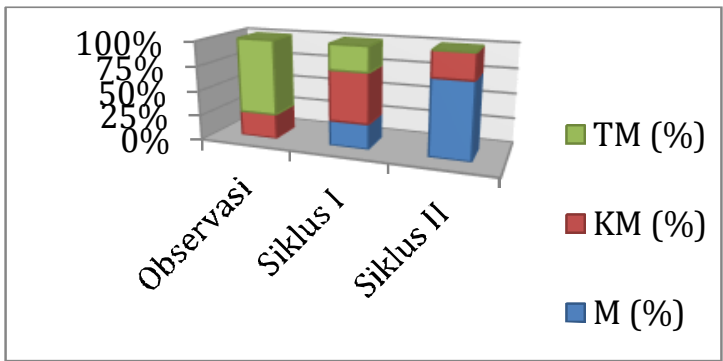




\section{Kesimpulan}

Berdasarkan penelitian yang dilakukan dapat diperoleh kesimpulan bahwa meningkatnya budaya menulis siswa tunagrahita pada mata pelajaran bahasa Indonesia menggunakan media kamus bergambar (Musbar) di kelas VII-VIII.C SLB Al-Azhar Bukittinggi dapat memberikan hasil yaitu : Respon dan minat siswa meningkat terhadap pelaksanaan pembelajaran Bahasa indonesia terutama dalam menulis meningkat. Kemampuan siswa dalam menguraikan kata menjadi bertambah selama proses pembelajaran.Fungsi guru sebagai fasilitator dan siswa sebagai student center, Siswa mengenal media belajar yang baru serta ikut membudayakan literasi menulis di sekolah

\section{Daftar Rujukan}

Demaja, Christina. 2004. Pengaruh Penggunaan Bahan Ajar dan Gaya Belajar Terhadap Hasil Belajar. Artikel. http://artikel1.us/christiana6- 04.html.

Peraturan Direktur Jenderal Pendidikan Dasar dan Menengah Nomor: 10/D/KR/2017 tentang Kurikulum 2013 PK-LK Kusmayadi, Ismail dkk. 2008. Belajar Bahasa Indonesia Itu Menyenangkan: untuk SD/MI Kelas I. Jakarta: Pusat Perbukuan, Departemen Pendidikan Nasional.

Suyatno, H dkk. 2008. Indahnya Bahasa dan Sastra Indonesia: Untuk SD/MI Kelas I. Jakarta: Pusat Perbukuan, Departemen Pendidikan. Direktorat Jenderal Pendidikan Dasar dan Menengah Kementerian Pendidikan dan Kebudayaan tahun 2016, Panduan Gerakan Literasi di SLB. Hadis, Abdul. Pendidikan Anak Berkebutuhan Khusus. Bandung: Alfabeta. 2006.

Smith, Chris Dukus. Cara Menangani Anak Berkebutuhan Khusus. Jakarta: Indeks. 2009. 